\title{
Mudanças no comportamento de consumo, percepção da imagem da marca e influência na decisão de compra: um estudo no setor de cosméticos
}

\section{Silvia Prata P. de Alvarenga (IC)}

\section{Resumo}

As marcas são, atualmente, um importante fator de diferenciação das empresas. Nessa perspectiva, pretende-se com este trabalho analisar qual a percepção dos consumidores em relação às mudanças nas estratégias adotadas pelas empresas e, principalmente, a respeito da importância das marcas.

\section{Palavras Chave: marketing, marcas, cosméticos}

\section{Introdução}

Influenciado pelos avanços das tecnologias da informação e da comunicação, pela convergência midiática e por diversos outros fatores, emerge, no contexto dos estudos de marketing, a figura do "novo consumidor", que dispõe de diversas informações e opções de entretenimento. A evolução do comportamento do consumidor indica a ascensão da chamada "economia afetiva", que convida o consumidor a entrar na comunidade da marca e envolver-se emocionalmente com os produtos adquiridos. Nesse cenário, a marca ganha importância em detrimento do preço como fator de diferenciação, sendo fundamental no processo de decisão de compra de cosméticos, assim como em outros setores produtivos.

O presente trabalho visa discutir o modo com que todas essas mudanças (do lado do consumidor e do lado das empresas) são percebidas pelos chamados "novos indivíduos" e como as marcas se tornam um elemento importante no processo de decisão de consumo, tendo-se como objeto de análise o setor de cosméticos no Brasil.

\section{Resultados e Discussão}

Em continuidade à pesquisa desenvolvida entre 2013 e 2014 com apoio do CNPq pelo programa PIBIC e com base em alguns dos resultados atingidos nessa primeira etapa, o projeto enviado ao PIBIC para ser implementado entre 2014 e 2015 propunha uma discussão sobre a importância das marcas na perspectiva dos consumidores.
A investigação para desenvolver este projeto orientou-se sobretudo pela revisão bibliográfica de textos que permitem entender as mudanças no comportamento do consumidor e as implicações para as relações empresa/consumidor.

A bolsa foi cancelada após quatro meses de pesquisa, o que inviabilizou a continuidade do projeto. O trabalho fica, portanto, restrito a suas etapas preliminares, correspondentes à pesquisa sobre o setor de cosméticos no Brasil e sobre o processo de construção e gestão de marcas.

\section{Conclusões}

O projeto não foi finalizado.

\section{Agradecimentos}

Fica um agradecimento especial à minha orientadora, Dra. Maria Carolina de A. F. de Souza, por todo o apoio em minha pesquisa e trajetória.

SOUZA, M. C. A. F. de; GORAYEB, D. S. Documento Setorial: Higiene Pessoal, Perfumaria e Cosméticos. Projeto PIB -

Perspectivas de Investimento no Brasil. Campinas: Instituto de Economia da Unicamp, 2009.

SOUZA, M. C. A. F. de. Técnicas de Desenvolvimento da Marca Fóruns Permanentes Empreendedorismo e Inovação. "como se constrói uma marca?”. Campinas: Unicamp, 5 de junho de 2012. Anotações da palestra. 